$\mid$ Pbilosophia $\quad$ Philosophia Scientiæ

Scientie Travaux d'histoire et de philosophie des sciences

CS $5 \mid 2005$

Fonder autrement les mathématiques

\title{
Proof in C17 Algebra
}

\section{Brendan Larvor}

\section{(2) OpenEdition \\ Journals}

Electronic version

URL: http://journals.openedition.org/philosophiascientiae/378

DOI: 10.4000/philosophiascientiae.378

ISSN: $1775-4283$

\section{Publisher}

Éditions Kimé

Printed version

Date of publication: 1 August 2005

Number of pages: $43-59$

ISBN: 2-84174-372-1

ISSN: 1281-2463

\section{Electronic reference}

Brendan Larvor, "Proof in C17 Algebra", Philosophia Scientiæ [Online], CS 5 | 2005, Online since 01 August 2008, connection on 16 January 2021. URL: http://journals.openedition.org/ philosophiascientiae/378; DOI: https://doi.org/10.4000/philosophiascientiae.378 


\title{
Proof in C17 Algebra
}

\author{
Brendan Larvor \\ University of Herfordshire
}

Résumé : Nous nous intéressons dans cet article à la naissance de la notion de preuve algébrique à partir des travaux de Cardano, Viète, Harriot et Pell. La transition de la preuve géométrique à la preuve algébrique passe par des références à la théorie eudoxienne des proportions dans le livre $\mathrm{V}$ d'Euclide. L'innovation cruciale dans la notation fut le développement des parenthèses. Au milieu du dix-septième siècle, la preuve géométrique devient insoutenable comme garant unique de rigueur parce que les mathématiciens avaient développé nombre de techniques qui ne pouvaient pas être justifiées en termes géométriques.

Abstract: This paper considers the birth of algebraic proof by looking at the works of Cardano, Viète, Harriot and Pell. The transition from geometric to algebraic proof was mediated by appeals to the Eudoxan theory of proportions in book $\mathrm{V}$ of Euclid. The crucial notational innovation was the development of brackets. By the middle of the seventeenth century, geometric proof was unsustainable as the sole standard of rigour because mathematicians had developed such a number and range of techniques that could not be justified in geometric terms. 
By the middle of the sixteenth century there was in Europe, on the one hand, geometry, which had well-established standards and methods of proof, and a large body of actual proofs. On the other hand, there was an emerging body of analytic techniques that did not have their own criteria or means of proof. These techniques developed naturally out of simple recipes for performing arithmetical calculations such as the rule of three or the various methods of long division. Having established techniques for finding square roots, it was natural for arithmeticians to extend these techniques to problems that we would nowadays express in quadratic equations (we still speak of the 'roots' of an equation). In short, geometers looked for theorems with proofs, but people doing what came to be called 'algebra' or 'specious analysis' were looking for solutions. This division is reflected in the titles of algebra books such as Cardano's Ars Magna [Cardano 1545] or Harriot's Artis Analyticae Praxis [Harriot 1631]. While the word 'ars' (art in the unromantic sense of craft or technique) was often used, the word 'scientia' is pointedly absent from these book titles. 'Scientia' was a highly contested term but the principal source of its meaning was still Aristotle's Posterior Analyt$i c s$, in which the title of science was reserved for systematic, deductive knowledge. In the sixteenth century, geometry was widely ${ }^{1}$ taken to fulfil this requirement while algebra did not. However, by the middle of the seventeenth century we find that algebra is able to offer proofs in its own right. That is, by that time algebraic argument had achieved the status of proof. How did this transformation come about?

This question could easily occupy an entire monograph. An apparently continuous historical narrative that registered the many small steps on the journey, and that paid due attention to the unevenness of the development (for fear of presenting an excessively streamlined and whiggish account) might need more than one book. Historical development is al-

\footnotetext{
${ }^{1}$ But not universally. See [Mancosu 1992]. This paper considers the debate following the publication in 1547 of the Commentarium de certitudine mathematicarum disciplinarum by Alessandro Piccolomini (1508-1578). According to Mancosu, Piccolomini attempted to refute "a widespread argument which aimed at showing the certitude of mathematics (asserted by Aristotle and reiterated by Averroes and a long list of Aristotelian commentators) arguing from the assumption that mathematics makes use of the highest type of syllogistic demonstrations" [Mancosu 1992, 244]. The chief point stands, since the mathematics to which this controversy refers is that of Euclid. As Mancosu put it, the question was, "What is the relationship between Aristotelian logic and Euclidean mathematics?" [Mancosu 1992, 242]. For Piccolomini and his fellow renaissance writers, the question did not arise with respect to the analytic art. Things were quite different a century later, when Hobbes, Wallis and Barrow took up the question of mathematical certainty afresh. Then, the status of algebra was at the centre of the dispute. See [Sasaki 1985].
} 
ways uneven, as there are always individuals ahead of their times and a greater number behind. The development of early modern algebra is especially uneven due to the diversity of sources: to an indigenous European tradition of reckoning were added rediscovered Diophantus and the works of Islamic mathematicians. Moreover, it was at about this time that national styles and rivalries started to flourish in European science. In view of these complexities, the most we can hope to achieve in a short paper is a comparison of snapshots taken at significant moments in the story. This paper offers a small collection of still photographs rather than the sort of cinematic sequence that gives an illusion of continuity.

Before we open the photo-album, permit me a methodological note. The initial sketch of a mathematics divided between problem-solving 'analysis' (arithmetic-cum-algebra) and theorem-proving geometry is broadly-speaking right. Indeed, some Renaissance mathematicians regretted this divide and dreamed of a unified, 'universal' mathematics ('mathesis universalis') [Sasaki 1985, 9192; Mancosu 1996, 86]. However, to set up this division as an absolute distinction is to make a mystery of the fact that it was eventually overcome. Absolute distinctions create insoluble historical problems (as Kuhn discovered). Instead, we should recall that to draw a distinction is at the same time to make a connection. That is, we must look for points in the historical record where the apparently absolute distinction breaks down. In other words, we look for intimations of proof and rigour on the un-rigorous, 'heuristic' side of the division: in the analytic practice; in the modes of argument; but also in the structure of the books themselves; and the language and notations used.

\section{Girolamo Cardano (1501-1576)}

The subject of our first snapshot is Girolamo Cardano's Arts Magna [Cardano 1545], in which he systematises and proves the thirteen solutions by radicals of the cubic. There are thirteen solutions because his proofs are geometric. He interprets the unknown as a line segment and the coefficients as lines, areas or volumes so as to preserve the homogeneity of the sum. ('Homogeneity' means that volumes are only added to volumes, areas to areas and so forth. To achieve this with a cubic equation, Cardano read the coefficient of the squared term as a line and that of the linear term read as an area, while he treated the constant term as a volume. Then, the whole equation is in volumes.) Consequently, he could only recognise positive coefficients (for what sense can be given to 
negative areas or volumes?), so rather than just the cubic he had thirteen variations. He had no symbolism (except the use of letters to label points on diagrams) and consequently none of the notational machinery nowadays associated with algebra. Rather, he wrote everything out in abbreviated prose and gave his proofs in the Euclidean style (see figure 1). This geometrical rigour constrained the scope of his algebra. For him there could be no rigorous treatment of equations of degree greater than three because "nature will not allow it" 2 . That is, there are just three dimensions in space, and geometry is the means of proof, so nothing can be proved about equations of degree greater than three.

This geometric standard of rigour was a source of difficulty for Cardano because in the appendix to Ars Magna he explains how to solve a certain class of bi-quadratics (this result was due to his student, Ferrari). What is the status of Ferrari's argument to show that his solutions of these bi-quadratics are correct? It cannot be proof (by Cardano's standards), yet it is entirely persuasive. This, though, is the least of Cardano's difficulties. Using modern notation, consider his solution by radicals of the 'irreducible' case of a cubic with three real roots. If $\boldsymbol{a}$ and $\boldsymbol{N}$ are positive and $x^{3}=a x+N$, then:

$$
x=\sqrt[3]{\frac{N}{2}+\sqrt{\left(\frac{N}{2}\right)^{2}-\left(\frac{a}{3}\right)^{3}}}+\sqrt[3]{\frac{N}{2}-\sqrt{\left(\frac{N}{2}\right)^{2}-\left(\frac{a}{3}\right)^{3}}}
$$

Obviously when $(N / 2)^{2}<(a / 3)^{3}$ the square roots are imaginary and the whole expression is complex. Nevertheless, the solutions are real. This is an early instance of a detour through the complex universe prompted by a question that makes no reference to complex numbers in either its statement or its solution. This problem was more serious than that posed by equations with complex roots, since in those cases Cardano could simply declare such roots impossible or nonsensical (as many mathematicians did). Cubics with three real roots cannot be so dismissed. Thus there was, for Cardano, a dilemma. On one hand, he had established standards of proof, on the other he had persuasive results that were impossible in principle to prove within these standards. As we shall see, this dilemma intensified in the succeeding century. What was, for Cardano, a small trickle of results that could not be modelled in the geometry of solids

2"For as positio refers to a line, quadratum to a surface, and cubus to a solid body, it would be very foolish for us to go beyond this point, nature does not permit it." [Cardano 1968, 9]. "Nanque cum positio lineam, quadratum superficiam, cubus corpus solidum referat, nae utique stultum fuerit, nos ultra progredi, quo naturae no licet." [Cardano 1570,6]. 
with finite magnitudes, broadened to a flood. In retrospect, we may (in a Popperian spirit) regard Cardano's irreducible cubics and Ferrari's biquadratics as 'refutations' of the metaphysics and methodology implicit in Cardano's geometric standards of rigour. However, we should note, first, that Cardano had no such perspective. Second, his anomalous cases might have remained as no more than recondite unsolved problems, and posed little threat to the established methodological order, had they not been but the first of many.

\section{François Viète (1540-1603)}

Viète's principal achievement is the introduction of a recognisably modern symbolism for variables, coefficients and some operations (though he still wrote everything else out longhand; note too the use of double lines to indicate subtraction). Nevertheless, Viète's algebra seems firmly within the tradition of problem-solving technique since he gives little or nothing in the way of proof. Consider, for example, Proposition XVI of his Ad Logisticen Speciosam Notce Priores [Viète 1646, 20], which is in fact a problem-to-solve rather than a hypothesis-to-prove: "To subtract the cube of the difference between two roots from the cube of their sum." The argument consists of a single sentence: "Let the individual solids making up the cube of $A-B$ be subtracted from the individual solids making up the cube of $A+B$." This is, strictly speaking, a procedure rather than a proof, and he carries it out in the next sentence to get the answer: in modern notation, $6 A^{2} B+2 B^{3}$ (see figure 2). However, we cannot conclude from the brevity of this discussion that Viète was indifferent to proof. Certainly, he hoped to illustrate the expressive power and heuristic efficiency of his symbolism. However, his texts have the form (if not the substance) of a deductive, 'scientific' system. He labels his problems as 'propositions' and his solutions as 'theorems', and he makes reference to Aristotle's Posterior Analytics [Viète 1983]. In particular he claims that theorems proved by his art conform to the laws governing the relation of attribute to subject, laid down in Posterior Analytics, Book I, Part IV. So in terms of the quaestio that Mancosu discusses, Viète claims for algebra (specifically, for his 'zetetics') the status attributed to Euclidean mathematics by Aristotelian tradition.

The fact that Viète could present a calculation with letters standing in for arbitrary quantities as a proof, however modest, indicates a change in the conception of number itself. Viète did not interpret numbers geometrically as Cardano did, even though he retained the old geometric 
DE ARITHMETICA LIB. X.

Decubo,quadratis \& pofitionibus zqualibus

numero. $\quad C A P . X V I L$

DIMONSTRATIO.

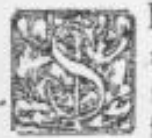

It gratia exempli cubus ab, $\& 6$ वृdrata, $\alpha_{2} \circ$ pofitiones xqualia too, \& addam b cad a b, qux fit 2, tertia pars nu meri quadratorum, \& defcribitur cubus uniuerfalis a c, fccundum quod componitur ex fuis octo partibus, crit igitur cubus a b,fd fuperficies cum fua altitudine, $\&$ cubus b c 8 , quia b ceft $2, \&$ a d corpora, 6 quadratis a b, xqualia, \& corpora de tz a b feu duodecuplo a b ex fexto capitulo huius libri, quia igitur cubus a b $\& 6$ quadrata $\& 20$ pofitiones, xquantur 100 , addans tur 8 pofitiones, qua funt reliquum ad zo politiones, cubo a c, qui iam aquebatur cubo a b, \& 6 quae dratis, \& 12 pofitionibus, \& cubob c, erit cubus a c cum 8 politionibus, ax: qualis to 8, nam cubus a c excedit trí corpora da, d e, in cubó c d, quîi eft 8 , at quia 8 pofitiones $a b$ deficiurit $\mathbf{a} b$, 8 pofitionibus a c cubi maioris, in 8 b c feu oftuplo b c, quxeft 2 , addes mus igitur oftuplum b c utriq pars ti, $\&$ fiet cubus $p: 8$ rebus, £qualis 124

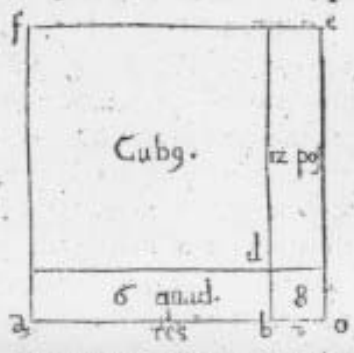
nota igitur ex capitulo fuo a c,auferemus b c, relinquitur a q. Sit ratr fus cubus a b, \& 6 quadrata \& 12 res, xqualia too, igitur addito cố muni cubo b c, erit cubus a c aqualis ro $8, \&$ a c R cubica $108, \& \mathrm{a}$ 'b 2 m:quàm a c cognita, fit dehuo cubus $\& 6$ quadrata a b \&2 pofitis ones equalia 100, addiris igitur 10 pofitionibus refiduis, ad cốplen dum corpora de, \& addito cubo b c, fiet cubus a c aqualis ro pofi. tionibus fuperadditis, 8108 , fed ro pófitiones a b deficiunt à to po fitionibus a c in $10 \mathrm{~b}$ c,addemus igitur $10 \mathrm{~b}$ curriqp parti,fiet cubus a cp:20, aqualis 10 pofitionibus p:108, abrice so exutraç parte, relinquetur cubus a c equalis to poficionibus $p: 88$, inuenta a $c_{2}$ mils nueb c \& relinquetura b neceffario cognita.

\section{RE G V L A.}

Regulaigirur communis eft, duc $3^{\text {tw }}$ partem numeri quadratos rum(quam hocfigno, Tp $\bar{d}$ d: demonftramus) ad cubum, addećp numero, inde duc numerum quadratorum in fui tertiam partem, \& produĉti differêtia à numerus rerum, eft numers rerum addendarü cubo, ubi productū fúcrit minus numero rerum propofitarum uel addendarum numero, ubi productum fueriemaius numero rerum propofitarū. Si igitur differentia eftnulla,producti \& numerirerü 
vocabulary of 'squares' and 'cubes' (as indeed we do today). That is why he felt no obligation to locate a 'line' in a diagram (it makes no sense, to use the example in hand, to ask about the relative positions of $A$ and $B$ ). By contrast, each of Cardano's proofs implies a diagram: the elements of the proof are elements of the diagram (line-segments, areas and volumes with determinate relative positions). The diagram is essential - it supplies the terms of the theorem with their meanings (though in fact not every proof in Ars Magna has a diagram printed with it, since the proofs are all rather similar, so having seen one diagram it is easy for the reader to supply the others). None of this holds for Viète, whose few diagrams appear late in the text, after his algebra is established. Another indication of this change is the fact that Viète was not bound to three dimensions, even in principle. Cubes of cubes make sense in Viète's mathematics. Cardano did work with negative and complex numbers, and did contemplate powers higher than three, but only when reckoning the solutions to problems. The change in the mode of mathematical reasoning between Cardano and Viète indicates a change in the conception of number precisely because it takes place in the context of proof, where philosophical niceties matter.

Viète's scientific aspirations for his algebra are clearest in the programmatic part of his work. At the start of chapter two of his Introduction to the Analytic Art [Viète 1591], he says, "Analysis accepts as proven the well-known fundamental rules of equations and proportions that are given in the Elements". There follows a list of 'rules', the first six of which are adapted from the common notions of Euclid. The remaining ten rules are adapted from book V of Euclid (sometimes attributed to Eudoxus of Cnidus), on ratio and proportion. He then claims that, "a proportion may be said to be that from which an equation is composed and an equation that into which a proportion resolves itself." 3 This formula is essential to the scientific status of Viète's art because it connects his analytic techniques with the theorem-proving side of mathematics. As one would expect given this fundamental principle, he argues in succeeding chapters for algebraic results on grounds drawn from the Euclidean theory of proportion. Like Cardano, then, Viète presented himself as a follower of Euclid. However, he appeals to book V only, and since this concerns proportion rather than geometry, it does not impose the same constraints as Cardano's standards of rigour. It is, therefore, less misleading to describe him as a follower of Eudoxus than as a follower of Euclid.

\footnotetext{
3"Itaque Proportio potest dici constitution æqualitatis. Æqualitas, resolutio proportionis" [Viète 1646, 2].
} 
In Viète, then, we have on the one hand an art with an aspiration to scientific status grounded by a sort of equivalence principle in Euclidean (or better, Eudoxan) tradition and presented as a body of theorems. On the other, we have a useful notational innovation that permits one to argue for general results, but which has not yet developed to the point where the manipulation of symbolic expressions counts as argument.

\section{Thomas Harriot (1560-1618)}

Thomas Harriot's Artis Analyticae Praxis [Harriot 1631] shares the scientific aspirations of Viète's algebra. Like Viète, Harriot lays down definitions and he orders his results into minor lemmas and major theorems. He celebrates a completed proof with Quad Erat Probandum or Quad Erat Demonstrandum. In spite of the title given to his work by others when it was published posthumously (Artis...), he evidently shared Viète's aspiration to establish algebra as a science. There is another similarity to Viète that connects Harriot with book V of Euclid. Look at his proof that the arithmetic mean of two unequal numbers is greater than the geometric mean (figure 3). Rather than start with the minimal assumption that $p>q$, and then multiply each side by $p-q$, he observes that $p^{2}, p q, q^{2}$ is a series in proportion and therefore he can immediately state that $p^{2}-p q>p q-q^{2}$. As in Viète, the theory of proportions in book V of Euclid is the assumed ground upon which the new science is to be built.

Another aspect of Harriot's scientific aspirations for algebra was his system of canonical equations. These are equations with straightforward solutions. Every non-canonical equation was associated with a canonical equation of the same degree, from which, Harriot hoped, it would be possible to solve the non-canonical case, or at least calculate the number and signs of the solutions. Harriot was not the first to attempt to classify equations. The point is that an objective taxonomy is part of what would distinguish a true science from an art or craft.

Harriot's notation was more highly developed than that of Viète. He employed Robert Recorde's familiar equality sign and the present-day symbol for inequality. He did not use superscripted numbers for exponents (we owe that to Descartes ${ }^{4}$ ), but instead repeated the letter or

\footnotetext{
${ }^{4}$ Descartes does not appear in this photo-album for two reasons. First, in his mathematics the relation between algebra and geometry is too complex and philosophically fraught to treat briefly. Second, in his epistemology he rejects formal deduction in favour of the lucid perception of clear and distinct ideas. For him, a
} 
20

A D LOCISTCBN SPEC.

Coxsacraxivu.

Drmyz $\pi$ n $z r$ A quadratorum fi adplicetur differentielaterum, erierur adgrega. tum laterum: 8 contra. Differentia quadratorum fi adplicetur adgregato laterom, orie. tur differentia laterum. Quandoguidem divifio reftitutio eft relolutione ejus operis, çuod compóitione maltiplicatio eflicit.

Propositio XV. C v s o adgregati duorum laterum, cubum differentix eorundem

S t 7 latus uoum $A$, alterum $B$. Oporteat $A+B$ cabo, $A=B$ cubum addere. At verd cubus effectus abs $A+B$, conftat $A$ cubo, $+A$ quadraro in $B$ ter, $+A$ in $B$ quadratam tet. $+B$ cubo. Cubus autem abs $A=B$ conitat $A$ cubo, $-A$ quadrate in $\mathrm{B}$ ter, $+\mathrm{A}$ in $\mathrm{B}$ quadratum ter, $-B$ cubo. Fiat igirur horumradditio : fumma eft $\mathrm{A}$ cubus bis, $+\mathbf{A}$ in B qadratum fesice. Hinc ordinatur

T u $\approx$ o $\mathrm{n}$ : $\mathrm{M}$ A.

C v s v s adgregati duorum laterum, plas cubo differentir corubdem, acuatur doplo cubo latens majoris, plus fextuplo folido a latere majore in lateris minotis qua-
dratam.

P R O P O S $t$ T t 0 XVI.

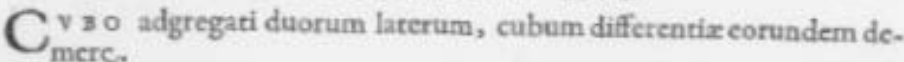

Six laras unam $A$, alterum $B$. Oporteat $A+B$ cabo, cubum $e x A=B$ demere. Abs folidis fingularibos, quibur conftat componendas abs $\mathrm{A}+\mathrm{B}$ cubas, demantur fingularia folida, quibus conitat cubusabi $A=B$ z orierur $A$ quadratum ja $B$ fexies, $T B$
cubo bis. Hive

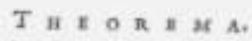

C v a y s adgregati duorum lateram minus cubo differentix eoruadem, zequatue fextuplo folido i Latere minore is quadratam majoris, plas duplo cubo lateris minotis.

$$
\text { P x o pos I t to XVII. }
$$

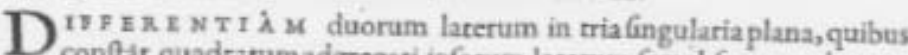
conflit quadratumadgregati ipforum laterum femel fumpta, duccre.

$S i \tau$ latus majos $A$, minus $B$. Oporteat $A-B$ ducere in $A$ quadratum, $+A$ in $B$, + B quadrato. Fist patticulatis dactio, \& colligantur fingulatia folida. Erunt illa $A$ cubus, - B cubo. Hise

$$
\text { T } n \geq 0 \geq \geq M \text { A. }
$$

Qv o $\mathrm{D}$ fit ex diffetentia duorum lateram in tria fingularia plana, quibus conftat goadratum adgregat ipforutu laterum femel fumpta, requale eft differentix cuborua.

$$
\text { Coxs } x \cos \text { i } \mathrm{v} x \text {. }
$$

Dro golatia plana, quibus coultat quadratum adgregati laterum femel fumpta. Et permutim,

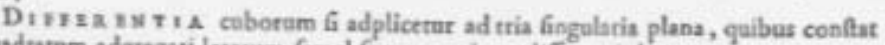
gasdratam adgregati laterum femel fampta, orietur differeatia laterum.

\section{P $x$ o pos $x$ T 10 XVIII.}

A DGR E A A $T$ V duorum laterum in tria fingularia plana, quibus 1 conftat quadrarum differentix ipforum laterum femel fumpta $\mathbf{g}$ du-
cere. 
expression: for our $p^{2}$ he wrote $p p$. Consequently, he could not have entertained fractional or complex exponents. However, there was a vital notational innovation: combinations of operations. Rather than use brackets, he expressed products of polynomials by listing the factors vertically, next to a vertical line. That is, for our $(a+b)(c-d)$, Harriot wrote $\begin{gathered}a+b \\ c-d\end{gathered} \mid$ (it is easy to imagine how this might have evolved out of the usual method for multiplying numbers). This capacity of Harriot's notation to combine symbols for operations made it sufficiently powerful to induce a qualitative difference from the work of Cardano and Viète. In Cardano, mathematical argument, expressed in Latin prose, made essential use of diagrams and appealed to geometrical intuition. As for Viète, what little argument he offered, he couched in a mixture of symbols and prose. That is because he had nothing to play the role of brackets. His notation did not allow him to combine operations and thereby create complex expressions. Rather, to avoid ambiguity, he had to fall back into prose. To return to the example above, he wrote $6 A^{2} B+2 B^{3}$ as "A quadratum in B sexies + B cubo bis". However, replacing a complex expression with an equivalent is the characteristic form of algebraic argument. It is precisely because Viète's notation did not allow this that he was unable to lay out his derivations explicitly, relying instead on his readers' numerical intuition. In Harriot, however, the manipulation of symbols counts as argument. The argument starts with the condition of the theorem expressed as an equation (or in the case in hand, an inequality). By a series of truth-preserving manipulations this is converted into the required conclusion. Cardano's great slabs of Latin prose have vanished, replaced by a terse commentary, the sole purpose of which is to distinguish each manipulation from its neighbours ("Ergo... Sed..."). It is at about this point that mathematics became "the discipline in which your pencil is smarter than you are'. That is, insight is still required but where this fails, one can go some distance by relying on the notation and its rules (though these are as yet implicit, so the project of proving their reliability cannot even be mooted).

deductive sequence is one intellectual intuition sliced into a series of lesser intuitions in order to accommodate the limits of human memory. Consequently, to divide the movement from premises to conclusion into a sequence of small steps can have pedagogic or psychological value only. By his own standards he had no logical requirement to do this: readers in whom the light of reason burns sufficiently brightly will see the truth of his claims. For more on Descartes and deduction see [Larvor 2001]. 


\section{2 \\ SECTIO QVINTA.}

\section{Sectio quinta in qua aquationum communium per canonicarum aquipollentiam, radicum numerus determinatur.}

\section{E F I N I T IO.}

D V x zquationes fimiliter graduate \& fimiliter affectx, quarum coefficiens vel co. efficientia (fi plura fint) \& homogeneum datü vnius coefficienti vel coefficientibus \& homogeneo dato alterius in fimplici inxqualitatis, maioritatis fcilicet \& minoritatis habitudine conformia funt, xquipollentes in fequentibus appelland $x$ funt. Quod fic rurfusinterpreșandum eft, quafi equali radicum numero pollentes. Hine eft quod zquationibus è radicibus binomijs generatis $\&$ earum reduetitijs, dequibus in fuperioribus tribus Sectionibus tractatum eft, Canonicarum nomen impofitum eft : quia factâ earum ad æquationes communes comparatione, fi fupradiatis æquipollentiæ con. ditionibus inter fe conuchiatt, ad radicom numerum in rquationibus communibus dignofendum \& determinandum canones fiuc exemplaria certa \& folennia fint. In conformitate igitur inter æquationum communium \& canonicarum coefficientia \& homogenea data inftituendâ, æquationum communium coefficientia \& homogenea formali canonicgrum partitioni fimiliter partienda funt, \& fimiles vtrinque partes fumen* $\mathrm{d} x$, feruatâ in parcium habitudine æftimandâ homogen̂ix lege, per reductionem fcilicet procuratâ homogeniâ s cum coefficientia \& homogenea data neceffariò heterogenea fint, \& de heterogeneorum inter fe habitudine nulla fieri poffit affimatio.

\section{Lemima . $\mathrm{x}$.}

Si quantitas fecetur in duas partes inæquales quadratum è dimidia totius maior eft facto è duabus partibus inæqualibus.

Si fint $p$. \& q. dure magnitudinis partes inæquales, eft $\cdots \cdots \frac{p+q}{2}$

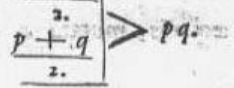

Nam è tribus continuè proportionalibus $p p . p q . q q$. quarum $p q$. maxima cet, $c c_{0}$ verò minima, eft ... $p p-p q>p q-q q$.

Ergo ......... $p p+q q>2 p q$.

Et addito vtrinq; $2 \cdot p q$. eft . : $p p+2 \cdot p q+q q>4 \cdot p q$

Sed ....... $p p+2 \cdot p q+q q=p+q$

$p+q$

Ergo ...... $\begin{gathered}|p+q| \\ p+q \mid\end{gathered}>4 p q$.

Ergo ...... $\frac{p+q}{\frac{p+q}{4}} \mid>p q$.

Figure 3: [Harriot 1631, 72] 


\section{John Pell (1611-1685)}

The final photograph is of the work of John Pell. This is inevitably a blurred image because Pell did not publish a work on algebra under his own name. Instead, we have An Introduction to Algebra, originally written in German by a Johann Rahn, translated into English by one Thomas Brancker "much altered and augmented by D. P." (title page), and published in 1668. Whatever the division of authorship between Rahn, Brancker and Pell, this work is interesting because in it the passage of algebra from geometry and prose to symbolic manipulation reaches its conclusion (though the development of the notation does not).

On the page reproduced here as figure 4, we find the recipe for Pythagorean triads. This is just one of many number-theoretic results in this work. The interest for our purposes is the division of the page into three columns. On the right, in the broadest column, the proof is carried out. In the narrow, middle column, each line of the proof has a number. In the left-hand column, each line has a note using previous linenumbers to explain how the current line of the proof was derived. These elements - numbered lines and comments - are now familiar to programmers and logicians. The comments themselves are easily standardised because there are only finitely many possible types of manipulation to get from one line to the next, namely the usual operations of arithmetic, plus the substitution of equivalent expressions. In place of Cardano's geometric standards of rigour, we now have a simple rule: make sure you apply the same operation to both sides of the equation. One could, in principle, check this syntactically.

This possibility was not lost on one of the leading mathematicians of the day. Leibniz dreamed of a language in which logical errors would show up as faulty grammar, as if in natural language "errors were due to solecisms or barbarisms". ${ }^{5}$ The development of algebraic notation meant that algebra had this property (or something very close to it) by the middle of the seventeenth century. That is, Cardano could have expressed faulty mathematical arguments in correct and elegant Latin, because there was no relationship between the syntax of the language and the rigour of the proof. Indeed, the science-minded philosophers of the seventeenth century tended to suspect that the literary skill of their humanist predecessors served precisely to disguise logical fallacies. In the language of algebra, however, faulty logic shows up as faulty syntax. It would be a long time before anyone was in a position to try to prove this,

\footnotetext{
${ }^{5}$ De scientia universalis seu calculo philosophico [Leibniz 1960 vol. VII, 200].
} 
not least because the modern notion of a wholly uninterpreted symbolism was not yet fully articulated. Nevertheless, the possibility of automated ('blind'), valid argument was discernible (to Leibniz at any rate) in the algebra of the mid-to-late seventeenth century.

\section{Disputes over the notion of proof}

Our sequence of four snapshots illustrates a change in the notion of mathematical proof in little over a century between Cardano (1545) and Pell (1668). Indeed, the crucial change was already present in Harriot's posthumous work of 1631, in which the manipulation of symbols is presented as proof. As we have seen, such manipulation was possible because Harriot's notation had a device equivalent to brackets, so he could distribute multiplication over addition. This richness permitted the substitution of equivalent expressions. Gathering terms and multiplying out brackets could now be done explicitly in the notation rather than merely described in prose. Therefore, the introduction of brackets is as important a step as Viète's use of letters for unknowns and coefficients. This shift in the notion of proof required the abandonment of Cardano's conception of rigour, dependant as it was on geometrical intuition. This change was part of the much larger philosophical and scientific turmoil of the time - Cardano published his Ars Magna two years after the publication of Copernicus' De revolutionibus orbium coelestium. In view of the intense contemporary debate about the philosophical foundations of scientific knowledge, it is implausible that mathematicians of the time did not ask whether these changes were compatible with rigour, even though our four chosen figures had relatively little to say about the nature of proof. Mention has already been made of the renaissance Quaestio de Certitudine Mathematicarum. As the seventeenth century opened the debate shifted its focus. Rather than accounting for the certainty of (Euclidean) mathematics, the problem was to understand the logical relations between different parts of mathematics. Algebra was only one new arrival: mathematicians had to contemplate complex numbers and indivisibles too. These changes have generated a rich historiography ${ }^{6}$, to which I hope to add just one point.

There was, by the middle of the seventeenth century, an accumulation of results that could not possibly be proved geometrically. These were

\footnotetext{
${ }^{6}$ See [Mancosu 1992; Mancosu 1996] for developments in France and Italy; [Sasaki 1985; Pycior 1997] for the English end of the story, and the Hobbes-Wallis-Barrow controversy in particular.
} 


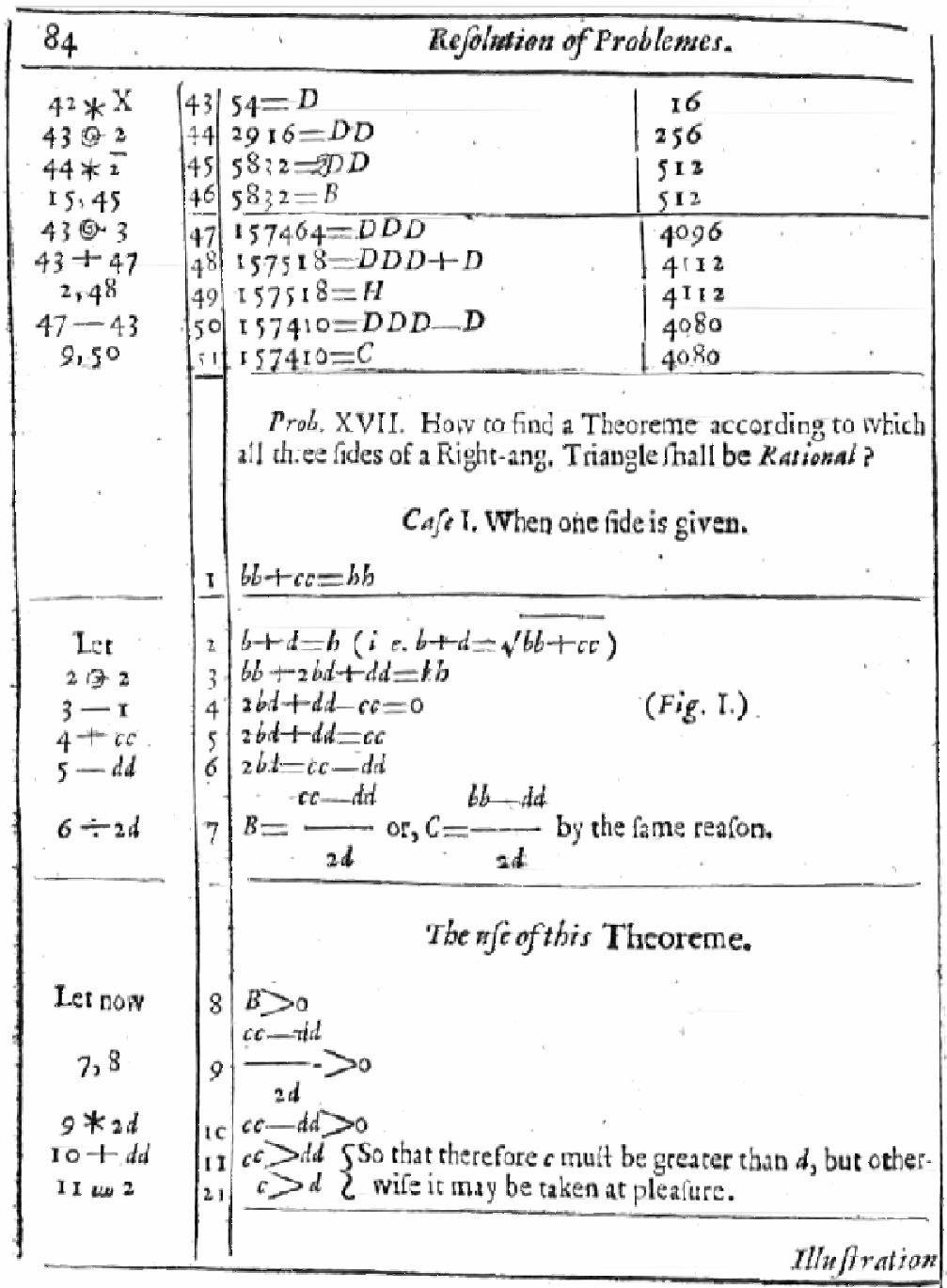

Figure 4: [Rahn 1668, 84] 
mostly number-theoretic results such as the sums of finite series (principally arithmetic progressions and powers thereof), or formulae such as the Pythagorean recipe taken from Pell's algebra above. Mathematicians explored the triangle of binomial coefficients ('Pascal's triangle'). Some of these (such as the Pythagorean recipe) could be proved using existing algebraic techniques, while others would have to wait for the development of proof by complete induction. In addition, equations themselves were becoming objects of study. Cardano noted that the complex roots of an equation occur in pairs, but had no means to prove it. The symmetric functions of coefficients were identified in Girard's L'invention nouvelle en l'algèbre of [Girard1629]. Descartes' 'rule of signs' for calculating the number of positive and negative roots of a real-valued equation from the changes in sign in the coefficients (intimated in Cardano and sometimes attributed to Harriot) had to wait until the eighteenth century for a rigorous treatment. In his algebra, Pell appealed to the modern sense of dimension: the number of data should equal the number of unknowns, or else the solution will be under- or over-determined. ${ }^{7}$ Cardano had to admit that a few rather recondite phenomena could not be treated within his standards of rigour. Since these were so few, he had the option of conserving his standards while noting the anomalies as such. His successors in the following century faced an avalanche of arithmetical and number theoretical results that could not be proved in Cardano's Euclidean style. Moreover, algebra began to distinguish itself from arithmetic as mathematicians discerned general features of equations (such as the symmetric functions or the rule of signs). As a result, the conservative horn of Cardano's dilemma disappeared. Faced with all this new material, mathematicians had no option than to abandon Cardano's geometrical standards of rigour.

\footnotetext{
${ }^{7}$ Wallis comments on this in his Treatise of Algebra [Wallis 1684, 214]. With reference to the remark above about national styles and rivalries, part of Wallis' aim is to argue Harriot's priority over Descartes. According to Wallis, everything purely algebraic in Descartes was already there in Harriot, and Descartes merely applied algebra to geometry [Wallis 1684, v]. Wallis produces no more than an anecdote in support of his claim that Descartes must have known of Harriot's work, and does not see any anachronism in projecting back to Harriot's time the notion of 'pure' algebra (as distinct from geometry).
} 


\section{References}

Cardano, G.

1545 Opvs novvm de proportionibvs nvmerorvm, motvvm, pondervm, sonorvm, aliarvmqve rervm mensurandarum, non solùm geometrico more stabilitum, sed etiam uarijs experimentis $\&$ obseruationibus rerum in natura... Praeterea Artis magnae; sive, De regvlis algebraicis, liber vnvs, abstrvsissimvs $\&$ inexhaustus plane totius arithmeticae thesaurus, ab authore recens multis in locis recognitus $\&$ auctus. Item, De aliza regvla liber, hoc est, algebraicae logisticae suae, numeros recondita numerandi subtilitate, secundum geometricas quantitates inquirentis, necessaria coronis, nunc demum in lucem edita, Basileae: Ex officina Henricpetrina, 1570; eng. trans. by T.R. Witmer: The great art: or, The rules of algebra, Cambridge, Massachusetts/London: the M.I.T. Press, 1968.

Girard, A.

1629 Invention nouvelle en l'algèbre, Leiden: Imprimé chez Muré frères, 1884, D. B. d. Haan (ed.).

HARRIOT, T.

1631 Artis analyticae praxis, ad Aequationes algebraicas nova, expedita $\&$ generali methodo resolvendas, London: Robert Barker, 1631.

LARVOR, B.

2001 Old Maps, Crystal Spheres and the Cartesian Circle, Graduate Faculty Philosophy Journal, 22(2), 13-27.

LEIBNIZ, G. W.

1960 Die philosophischen Schriften von Gottfried Wilhelm Leibniz. Hrsg. von C.I. Gerhardt, Hildesheim: G. Olms Verlagsbuchhandlung, 1960, K. I. Gerhardt (ed.).

Mancosu, P.

1992 Aristotelian Logic and Euclidean Mathematics: Seventeenthcentury Developments of the Quaestio de Certitudine Mathematicarum, Studies in the History and Philosophy of Science, 23(2), 241-265.

1996 Philosophy of Mathematics and Mathematical Practice in the Seventeenth Century, New York/Oxford: Oxford University Press, 1996.

PYCIOR, H. M.

1997 Symbols, impossible numbers, and geometric entanglements: British algebra through the commentaries on Newton's Universal 
arithmetick, Cambridge, U.K/New York: Cambridge University Press, 1997.

Rahn Johann, H.

1668 An introduction to Algebra, translated out of the High-Dutch into English, by T. Branckner... Much altered and augmented by D. P. [i.e. Dr. John Pell.] Also a table of Odd Numbers less than one hundred thousand, shewing those that are incomposit, and resolving the rest into their factors or coefficients, $\mathscr{E} c$., London: W. G. for Moses Pitt, 1668.

SASAKI, C.

1985 The Acceptance of the Theory of Proportion in the Sixteenth and Seventeenth Centuries-Barrow's reaction to the Analytic Mathematics, Historia Scientiarum, 29, 83-116.

VIÈTE, F.

1646 Opera mathematica in unam volumen congesta ac recognita, Lugdunum Batavorum: Elzevir, 1646.

1591 Opus restitutae mathematicae analyseos, seu algebra nova, 1591; eng. trans. by Wilmer, T. R. The analytic art, Kent (Ohio): Kent State University Press, 1983.

WALLIS, J.

1684 A treatise of algebra, both historical and practical, London: printed by John Playford; Oxford: Richard Davis, 1685, 1684. 